\title{
Nutrition Improvement of Elementary Students with Intervention of Tilapia Fish Flour and Sardine Fish Flour Based Biscuits
}

\author{
Slamet Widodo ${ }^{1, *}$, Saifuddin Sirajuddin ${ }^{2}$ \\ ${ }^{1}$ Universitas Negeri Makassar, \\ Makassar, Indonesia \\ ${ }^{2}$ Universitas Hasanuddin, \\ Makassar, Indonesia \\ ${ }^{*}$ Corresponding author's email: slamet.widodo [AT] unm.ac.id
}

\begin{abstract}
The objective of this research is to analyze the influence of tilapia and sardine flour based biscuits on the improvement of anthropometry nutritional status of Fifth Grade elementary school students. The research design is Pre-post Study Single Blind Randomized Controlled Trial (RCT). There were 26 respondents, consisting of 2 groups. They were given biscuits for 60 days. The weight and height of the children were measured before and after the intervention. Analysis method used is paired t test. The results showed changes in initial and end in consumption, energy control $30.8 \pm 3.9 \mathrm{kcal}$, treatment $50.6 \pm 8.6 \mathrm{kcal}$, protein control $12.5 \pm 1 \mathrm{~g}$; treatment $21.6+2.4 \mathrm{~g}$. Controlled weight change is $26.7+0.8 \mathrm{~kg}$ to $27.3+1.1 \mathrm{~kg}$, treatment $26.3+0.7 \mathrm{~cm}$ to $27.8+1.0 \mathrm{~cm}$. Increased weight after consuming the biscuits concluded that the biscuits may improve the malnourished children to normal nutrients children. Conclusion: provision of nutritional biscuits for 60 days improved weight/age, weight/height of Fifth Grade Elementary School Students.
\end{abstract}

Keywords---- Biscuit, Malnutrition, Tilapia Flour, Sardine Flour

\section{INTRODUCTION}

The basic capital for development is the improvement of Indonesian people quality and empowerment of its population. High quality citizen is achieved if the population is healthy, strong, and intelligent. One of the efforts in health has major impact on improving the quality of life and community nutrition. Good nutrient status shall be able to shape Indonesian as superior breeders, thinkers, with superior muscle performance.

Children are the most valuable capital as the next generation of the nation. The future of the nation is highly determined by the children. If children experience malnutrition, they will be susceptible to infectious diseases. Therefore, it is necessary to pay attention to the nutrition of children since they were in the womb up to toddler phase. Those are critical time for growth. The 2013 Riskesdas results showed that the national malnutrition prevalence was $13.9 \%$, while South Sulawesi was in the tenth position and in 2015, Luwu District was 13.9\% [1]. Malnourished students in Indonesia is located at the rural area (15.3\%), with farmers/fishermen/laborer parents (15.8\%), and those parents did not finish Elementary School (32.3\%)[2].

During the time of growth and development, children need intake of high nutrients. The rapid growth and loss of passive immunity are in the period from the start of weaning until the age of five, which is a life-prone period. If a child does not get special attention, then the child is prone to nutritional problems [3][4][5][6]. Thus, the child should be given care in the form of proper care, especially in the food nutrients. Care given by the mother will influence the eating habits of the children and will further shape the food consumption pattern of the children. During the school age, children malnutrition is a serious obstacle to the efforts to educate the children because malnutrition causes them to become weak, fatigued, sick, and decreased concentration while studying [7][8][9].

The nutrition problems for school children is optimized and handled through diversification of additional food formula development, taking into account the aspects of nutrition, health benefit, absorption, endurance, and superior local food resources. The local food resources are, among others, tilapia fish. The potential food that contains nutrients is tilapia fish, which is one of the animal protein source. Animal proteins are referred to as complete and high-quality proteins because they contain complete essential amino acids and their structure is similar to the amino acids that the body needs, and it has high digestibility, thus the absorbed amount is also high [10]. In the tilapia fish, the content of protein per $100 \mathrm{~g}$ is $20 \mathrm{~g}$ higher than eggs, i.e. $12.8 \mathrm{~g}$, chicken meat of $18.2 \mathrm{~g}$, and beef of $18.8 \mathrm{~g}$. But tilapia has a lot of bones and is very risky if the consumption is not careful [3][2].

Therefore, tilapia fish needs further processing to avoid the risks. One of the technique is to maximize the benefit of tilapia fish by processing it into flour. This type of flour is a type of material that can be used in various food 
processing. The flour is then processed into biscuit as biscuit is a type of snack with high durability and is preferred by all people, including elementary students. Additional food in the form of biscuit with the substitution of tilapia fish flour and sardine fish flour will be given to the students. Biscuit has the advantage because it is very practical, the toddler likes it as it comes in any flavor and form, and it is quite filling. The Research aims to evaluate the role of tilapia flour and sardine flour based biscuit to the nutritional status of malnourished student of 10-11 years old.

\section{Research Design}

\section{MATERIALS AND METHODS}

Intervention research is conducted in 60 days. The research design is Pre-post Study Single Blind Randomized Controlled Trial (RCT), i.e. the respondent does not know the type of treatment given. Type of treatment includes the provision of biscuits with additional tilapia fish flour and sardine fish flour, hereinafter referred to as the treatment group, and the provision of biscuits without tilapia fish flour and sardine fish flour, hereinafter referred to as the control group. The biscuits have similar shape, weight, and packaging. Treatment and control biscuits have the same protein and energy content (similar) but have different protein sources

\section{Ingredients}

The research used biscuits. The biscuits are substituted with tilapia fish flour and sardine fish flour, which is referred to as treat biscuit (F1), and biscuit without tilapia fish flour and sardine fish flour or control biscuit (F0), as a result of the previous acceptance experiment conducted. Both biscuits have the same color and are packaged inside the same aluminum foil. The control biscuit formula (F0) comprises $47 \mathrm{~g}$ wheat flour, $12 \mathrm{~g}$ margarine, $29 \mathrm{~g}$ egg yolks, $12 \mathrm{~g}$ refined sugar. The treat biscuit formula (F15) consists of: $25 \mathrm{~g}$ wheat flour, $8 \mathrm{~g}$ meizena, $6 \mathrm{~g}$ tapioca, $8 \mathrm{~g}$ tilapia fish flour and sardine fish flour, $12 \mathrm{~g}$ margarine, $29 \mathrm{~g}$ egg yolks, $12 \mathrm{~g}$ refined sugar. The nutrient content of the control biscuit (F0) is: energy $(476.03 \mathrm{Kcal})$, protein $(7.72 \mathrm{~g})$, fat $(17.43 \mathrm{~g})$, carbohydrate $(72.07 \mathrm{~g})$, fiber $(4.51 \mathrm{~g})$, ashes $(0.5 \mathrm{~g})$, and water $(2.03 \mathrm{~g})$. The content of treatment biscuit $(\mathrm{F} 1)$ is: energy $(500.33 \mathrm{Kcal})$, protein $(13.59 \mathrm{~g})$, fat $(24.77 \mathrm{~g})$, carbohydrate $(55.76 \mathrm{~g})$, fiber $(5.55 \mathrm{~g})$, ashes $(1.4 \mathrm{~g})$, and water $(4,48 \mathrm{~g})$ [10], [2].

\section{Place and Time}

The study is conducted in three Elementary School in the Lamasi Subdistrict, Luwu Regency. The location selection is based on the prevalence of malnutrition in the three elementary schools of the region, as they are among the highest $80 \%$ and are the highest in the Lamasi Subdistrict and did not change within the last 5 years. The attendance rate is $82 \%$ for the last 6 months. The study was conducted in January 2018-August 2018 with a 60-day duration of biscuit provision (January-March 2018)

\section{4. $\quad$ Subject}

The subject of this research is 10-11 years old fifth grader. The technique of Subject selection uses purposive sampling, i.e. a technique to choose Subject with certain considerations [11]. Screening of the research subjects is conducted through several stages: (1) to choose the students based on school data, (2) children of 10-11years (Fifth Grade), (3) malnourished 10-11 years old students, (4) home visits to provide explanation of research, approval, and completion of research informed consent; (5) clinical examination by physicians related to congenital diseases, (7) subsequently randomized provision of treat biscuit and control biscuits. The subject size is determined based on the formula [12] and weight change research results conducted by Widodo Annually 2015 [3], Thus, we obtained 10 samples. To anticipate the occurrence of a dropout subject, Total is enlarged with an estimated failure rate of about $30 \%$, Thus, each group needs 13 Subjects as the samples. Because there are 2 groups, the total children $=2$ groups times $13=26$ students.

\section{Data/Measurement Source}

Data collected before and after the intervention consisted of daily consumption, biscuit consumption compliance, daily consumption of biscuits during intervention, and weight and height before and after intervention. Data on compliance of taking the intervention biscuits were obtained from the monitoring forms, which contained the number of biscuits distributed to children each week. Compliance rates were calculated by adding the biscuits consumed by the child for 60 days divided by the number of biscuits that should be consumed by the child for 60 days. The compliance criteria include: (1) incompliance, if the compliance is $<70 \%$; (2) compliance, if the compliance is $\geq$ $70 \%$ [13],[14]. The data of $2 \times 24$ hours food recall is used to control the daily food consumption of the respondents [3]. 


\section{Data Analysis}

The analysis of baseline and endline data in one treatment uses paired t-test statistic to test the difference of average of two dependent Subjects and normal-distributed data. The test between treatment uses paired T-test to test the average difference of standard biscuit and treat biscuit, with normal-distributed data [11]

\section{Biscuit Consumption Compliance}

\section{RESULT AND DISCUSSION}

Tingkat kepatuhan konsumsi biskuit fungsional antar waktu pemantauan (bulan pertama hingga bulan kedua) menunjukkan adanya kecenderungan penurunan yang tidak tajam pada kelompok kontrol maupun pada kelompok perlakukan.

Table 1: Compliance Rate of Biscuit Consumption by Intervention Time and Treatment Group

\begin{tabular}{|l|c|c|c|c|}
\hline \multirow{2}{*}{ Time } & \multirow{2}{*}{$\begin{array}{c}\text { Maximum } \\
\text { Consumption }\end{array}$} & Control Group & Intervention Group & \multirow{2}{*}{ p Value } \\
\cline { 3 - 5 } & & Mean \pm SD & Mean \pm SD & \\
\hline Days (g) & $60(100 \%)$ & $53,6(89,4 \%) \pm 5,7$ & $52,7(87,8 \%) \pm 5,3$ & 0,502 \\
Weeks (g) & $420(100 \%)$ & $377,7(89,9 \%) \pm 33,5$ & $364,9(86,9 \%) \pm 30,4$ & 0,180 \\
Months I (g) & $1800(100 \%)$ & $1640(91,1 \%) \pm 147,8$ & $1627,3(90,4 \%) \pm 135,1$ & 0,790 \\
Months II (g) & $1800(100 \%)$ & $1578,1(87,7 \%) \pm 208,6$ & $1491,2(82,8 \%) \pm 182,9$ & 0,081 \\
60 days (g) & $3600(100 \%)$ & $3218,1(89,4 \%) \pm 340,0$ & $3160,8(87,8 \%) \pm 319,2$ & 0,502 \\
\hline
\end{tabular}

Notes: $\mathrm{p}>0.05$ : not significant.

The average total biscuits consumed by research subjects for 2 months amounted to $3160.8 \pm 319.2$ grams out of the recommended 3600 grams or (87.8\%) for the intervention group, and 3218.1 340.0 out of the recommended 3600 grams or $(89.4 \%)$ for the control group. The average consumption of biscuits substituted with tilapia fish flour and sardine flour (treatment biscuits/F1) contributes to $267.3 \pm 27$ kcal energy per day (13.1 $\pm 1.3 \%$ RDA) and $6.2 \pm 0.6$ grams protein per day $(10.6 \pm 1.2 \%$ RDA). Whereas, biscuits without tilapia fish flour and sardine fish flour (control biscuits/F0) contributes to $255.3 \pm 27 \mathrm{kcal}$ energy per day $(12.4 \pm 1.3 \%$ RDA) and $4.1 \pm 0.4$ grams protein per day (7.2 $\pm 0.8 \%$ RDA)

The level of biscuit consumption compliance based on the intervention period can be seen in Table 1 and Table 2. The biscuit consumption compliance, both for treatment biscuit and control biscuit, decreased by time, i.e. $90.4 \%$ during the first month of intervention to $82.8 \%$ in the second month for the treatment group, and $91.1 \%$ during the first month of intervention to $87.7 \%$ in the second month for the control group. This is smaller than the results of the study of biscuits in Bangkalan of $92.8 \%$ [14], but higher than the biscuit study of Widodo in Pare-Pare of 72.1\% [15], and Sari in Bogor of $76.6 \%[16]$, Biscuits substituted with tilapia fish flour and sardine flour is a new biscuit type in Indonesia, which is good for children and provides a compliance response at the beginning of the administration, in contrast to freshwater fish-based biscuits (cork fish) that are not ordinary to be consumed and become an intervention for malnourished children in Bogor and Pare-Pare. Thus, this is one of the reasons for the differences in the level of compliance of biscuits in this study, as well as the influence of caregivers in supporting the consumption of biscuits during the intervention

Biscuit consumption compliance is influenced by caregivers, teachers, and peers, who express love and feel the benefits of nutrition and health after taking the PMT biscuits. Good carer, teacher, and peer respondents' responses to the PMT biscuit delivery are mostly from the low-income families with less availability of alternative food choices for students. According to Hartog et al. Culture of eating is an important factor in the process to receive new product. The new product will be more easily accepted if the product is considered to be in accordance with a strong concept of what can be eaten and technically applicable in the region [17][18]. Similar thing is also reported by [19][20][21], the higher a person's compliance to take part in a research program, the higher the increase for the final outcome of the intervention, and vice versa. If a person does not comply with the program, it will result in less than optimal results for the research program. Compliance is influenced by internal (fondness and forgetfulness) and external (family and school environment) factors [22][23],

2. Biscuit Contribution to the Intake of Children's Energy and Protein The energy and protein intake, and the RDA percentage from the daily consumption of biscuits, are presented in Table 2. 
Table 2: Average Energy and Protein intake, and RDA Percentage from Daily Biscuit Consumption

\begin{tabular}{|l|c|c|c|}
\hline \multicolumn{1}{|c|}{ Nutrition Variable } & Control Group & Intervention Group & \multirow{2}{*}{ p Value } \\
\cline { 2 - 3 } Energy (Kcal) $(\mathrm{n}=13)$ & Mean \pm SD & Mean \pm SD & \\
Intake (Male = 2100; Female = 2000) & & & 0,102 \\
AKG (\%) & $255,3 \pm 27,0$ & $267,3 \pm 27,0$ & 0,087 \\
\hline Protein (Gram) (n=13) & $12,4 \pm 1,3$ & $13,1 \pm 1,3$ & \\
Intake (Male = 56; Female = 60) & & & $0,000^{* *}$ \\
AKG (\%) & $4,1 \pm 0,4$ & $6,2 \pm 0,6$ & $0,000^{* *}$ \\
\hline
\end{tabular}

Notes: $\left.{ }^{* *}\right)=p<0,01=$ very significant different control and intervenstion group

Table 2 shows that the consumption of standard biscuits provides an average contribution of energy, statistically different than the consumption of treat biscuit. But the average intake of RDA contribution on the children with treat biscuit has significant difference $(\mathrm{p}<0.05)$, higher compared to the one who got control biscuit. The biscuit consumptions contribute to $267.3 \pm 27 \mathrm{Kcal}$ energy per day $(13.1 \pm 1.3 \%$ RDA) and $6.2 \pm 0.6 \mathrm{~g}$ protein per day $(10.6 \pm 1.2 \%$ RDA). This is higher than the Galla et al result, of $11.3 \pm 0.3 \%$ energy RDA and $8.88 \pm 0.2 \%$ protein RD [24], However, our result is lower compared to the research conducted by Sari et al, i.e. $14.64 \pm 4.62 \%$ energy RDA, and $14.75 \pm 75 \%$ protein RDA [16]. The difference in consumption is due to the different consumption of biscuits.

High consumption of energy and protein when the children experience a lack of energy and protein will have a positive impact on the acceleration of the recovery of the child's body. The intake amount consumed by children depends on the selection of ingredients that are rich in energy and protein and the types of processed foods preferred by the children themselves. The biscuit consumption with the addition of tilapia fish flour, sardine fish flour, and red rice flour, which are familiar ingredients for children, will assist the children to accept the biscuits made from those ingredients. Thus, the children will consume biscuits that are rich in energy and protein. For this reason, consuming biscuits can increase energy and protein consumption. Enough consumption of energy and protein will help the growth of the children and avoid the negative effects caused by lack of energy and protein, such as low body weight, thin, sleepiness at school, laziness, and may cause the children to have lack of enthusiasm for learning, which ultimately may reduce their achievement.[21],[25],[26],

Table 3: The Average Intake of Energy and Protein from Daily Consumption of Food Without Biscuits

\begin{tabular}{|l|c|c|c|}
\hline \multirow{2}{*}{ Nutrition Variable } & Control Group & Intervention Group & \multirow{2}{*}{ P value } \\
\cline { 2 - 4 } & Mean \pm SD & Mean \pm SD & \\
\hline Energi (Kcal) & & & 0,471 \\
Early & $1507,05 \pm 142,55$ & $1464,71 \pm 140,95$ & $0,005^{* *}$ \\
End & $1538,03 \pm 139,00$ & $1726,35 \pm 118,21$ & \\
Early-End & $30,99 \pm 72,53$ & $261,64 \pm 106,67$ & \\
P value (Early-End) & 0.149 & $0,000^{* *}$ & 0,182 \\
Protein (g) & & & 0,097 \\
Early & $44,21 \pm 5,14$ & $40,86 \pm 4,36$ & $51,02 \pm 9,59$ \\
End & $56,71 \pm 3,78$ & $10,17 \pm 7,56$ & $0,000 * *$ \\
Early-End & $12,5 \pm 4,41$ & $0,000 * *$ & \\
P value (Early-End) & & & \\
\hline
\end{tabular}

Notes: $\left.{ }^{* *}\right)=p<0,01=$ very significant different control and intervenstion group

Based on the daily biscuit consumption of children, the intake of energy and nutrients and contribution to the nutritional adequacy of children (RDA percentage) can be seen. Recommended energy and protein RDA for 10-11 years old children, i.e. 2,100 Kcal energy (10-12 years) and 60g protein [1]. BPOM has published guidelines on the development of child food formulas. The energy to be served for every $100 \mathrm{~g}$ of the product, is at least $400 \mathrm{Kcal}$ [27]. The older the children, the greater the need for nutrients in food. An intervention program devoted to toddlers suffering from KEP problems is known as PMT-P (supplementary feeding), containing 300-400 kcal and 6-8 g protein [27]

The average protein contribution in the control group was $47.3 \%$. The average RDA protein for treatment group is $44.1 \%$. The paired t-test results show that there is real difference $(\mathrm{p}<0.01)$. This means that the additional 
contribution of protein intake from biscuit consumption treatment for 60 days of intervention differs between groups. The tilapia fish protein also contains all of the essential amino acids in sufficient quantities (Astawan 2009). Treatment biscuits contain about $8.15 \mathrm{~g}$ of dietary protein $(50 \mathrm{~g})$ or equivalent to $13.59 \%$ of targeted RDA protein in children. Thus, it meets criteria [27], in which the food is a good source of protein. Adequacy of nutritional consumption of children, is also influenced by the addition of biscuits, which is determined by daily consumption which includes the amount and type of food [28][29]. The results of t-test show that at the end with the initial intervention of daily dietary intake in control and treat biscuits, the differences were significant $(p<0.01)$ on intake and energy adequacy, and $\mathrm{p}<0.05$ on protein.

Table 4: Level of Energy and Protein Adequacy Without Biscuits Based on RDA

\begin{tabular}{|l|c|c|c|}
\hline \multirow{2}{*}{ Nutrition Variable } & Control Group & Intervention Group & \multirow{2}{*}{ P Value } \\
\cline { 2 - 4 } & Mean \pm SD & Mean \pm SD & 0,486 \\
Energi (\% RDA) & & & $0,006^{* *}$ \\
Early & $73,7 \pm 7,3$ & $71,6 \pm 7,2$ & \\
End & $75,2 \pm 7,3$ & $84,4 \pm 6,1$ & \\
Early-End & $1,5 \pm 3,5$ & $12,8 \pm 5,3$ & \\
P value (Early-End) & 0,144 & $0,000^{* *}$ & 0,207 \\
\hline Protein (\% RDA) & & & 0,116 \\
Early & $76,2 \pm 10,5$ & $70,3 \pm 8,0$ & \\
End & $97,8 \pm 9,1$ & $87,8 \pm 16,8$ & $17,5 \pm 13,2$ \\
Early-End & $21,5 \pm 7,4$ & $0,000^{* *}$ & \\
P value (Early-End) & $0,000^{* *}$ & & \\
\hline
\end{tabular}

Notes: $\left.{ }^{* *}\right)=p<0,01=$ very significant different control and intervenstion group

Table 4 shows that the mean difference in intake and the level of energy and protein adequacy of daily food intake after prior intervention in the treatment group was higher but not significantly different $(p>0.05)$ than the control group on the energy intake. However, it differs in the protein intake, which was very significant both the beginning, the end, and the difference itself $(\mathrm{p}<0.01)$.

\section{Efficacy of Biscuits on Nutritional Status}

Weight is one of anthropometry measurement that provides an overview of body mass and changeability. Weight measurements were first performed before the provision of biscuits and subsequent measurements are conducted once a week during the 60-day period..

Table 5: The Average Increase in Anthropometric Size During the Intervention

\begin{tabular}{|l|c|c|c|}
\hline \multirow{2}{*}{ Anthropometric } & Control Group & Intervention Group & \multirow{2}{*}{ P Value } \\
\cline { 2 - 4 } & Mean \pm SD & Mean \pm SD & \\
Weight (kg) & & & 0,605 \\
Month 0 & $30,1 \pm 4,1$ & $31,4 \pm 8,5$ & 0,520 \\
Month 1 & $30,9 \pm 4,1$ & $32,5 \pm 8,3$ & 0,484 \\
Month 2 & $31,6 \pm 4,2$ & $33,5 \pm 8,5$ & \\
Month 0 - Month 2 & $0,006^{* *}$ & $0,014^{*}$ & 0,210 \\
\hline Height (cm) & $133,8 \pm 4,9$ & & 0,199 \\
Month 0 & $133,9 \pm 4,7$ & $137,5 \pm 8,6$ & 0,200 \\
Month 1 & $134,2 \pm 4,4$ & $137,7 \pm 8,7$ & $137,9 \pm 8,8$ \\
Month 2 & 0,151 & $0,020^{*}$ & \\
Month 0 - Month 2 & & & \\
\hline
\end{tabular}

Notes: $\left.{ }^{* *}\right)=p<0,01=$ very significant; ${ }^{*}=\mathrm{p}<0,05=$ significant different control and intervention group

Table 5 shows that in general, all the respondents experienced weight gain even though it was small. However, the height did not change. The weight gain in the second month in the treatment group was faster than the control group. 
This is due to the role of nutrients in biscuits treatments which were more effective to increase body weight than the control group. Thus, it was affecting the weight. Height increase of both groups during the intervention were almost the same, unchanged. This is understandable considering the height increases slower.

Height is an anthropometry that describes the state of skeletal growth and is relatively insensitive to change in a short time. Table 5 shows in the first to the third month the largest average increase in body height is the treatment group at all ages. In the 60 days period of the intervention (beginning to the end), the treatment group showed a weight gain. Different T-test results in both groups showed no difference $(\mathrm{p}>0.05)$. This shows that the consumption of tilapia fish flour based biscuits have not been able to increase the height of malnourished 10-11 years old children. The distribution of students based on nutritional status with some $\mathrm{Z}$ score indicators is presented in Table 6 .

Table 6: Distribution of Respondents by Category of Nutritional Status at the Beginning and End of Intervention

\begin{tabular}{|l|c|c|c|c|c|c|c|c|}
\hline \multirow{2}{*}{ Status Gizi } & \multicolumn{4}{|c|}{ Control Group } & \multicolumn{4}{c|}{ Intervention Group } \\
\cline { 2 - 10 } & \multicolumn{2}{|c|}{ Early } & \multicolumn{2}{c|}{ End } & \multicolumn{2}{c|}{ Early } & \multicolumn{3}{c|}{ End } \\
\cline { 2 - 10 } & $\mathrm{N}$ & $\%$ & $\mathrm{n}$ & $\%$ & $\mathrm{n}$ & $\%$ & $\mathrm{~N}$ & \\
\hline Weight/Age & & & & & & & & \\
Malnutrition & 11 & 84,6 & 10 & 76,9 & 10 & 76,9 & 8 & 61,5 \\
Normal & 2 & 15,4 & 3 & 23,1 & 3 & 23,1 & 5 & 38,5 \\
\hline Weight/Height & & & & & & & & \\
Thin & 13 & 100 & 13 & 100 & 12 & 92,3 & 10 & 76,9 \\
Normal & 0 & 0 & 0 & 0 & 1 & 7,7 & 3 & 23,1 \\
\hline
\end{tabular}

Table 6 based on indicator of weight/age generally did not indicate any improvement in the nutrition after 60 days of biscuit. However, during the intervention, 1 student experienced nutritional improvement. Improvement of nutritional status of students is reflected in the decrease of respondents with less nutrition category. There was no improvement in the category of nutritional status of the weight/height category in both control and treatment groups, although the increase in nutritional status category was not much. This is in contrast to the weight/age category, which was fixable in a short period of time.

One of the indicators to assess nutritional status is to use a Z-score. Weight/age indicator measures the body mass, physical growth rate, and nutritional status. Height/age measures the past and present nutritional status. Weight/Height measures the current nutritional status [3]. Similar results are shown in the research results [30] in Ethiopia, the height growth can be hampered if a child has a protein deficiency (even though energy consumption is sufficient) for a long period of time. Meanwhile, body weight is more influenced by the lack of energy consumption [30][31].

The results of the study show that parenting patterns are the ability of families and communities to provide time, attention, and support for children to grow and develop as well as possible physically, mentally, and socially. Elementary school age is the second golden age for the growth of children, both physically and mentally, which affects the future. The malnutrition condition, such as stunting, is experienced by school-age children, which will affect the ability to learn in school and may affect their learning achievement. The results of this study are supported by the opinion of Picauly and Toy (2013) and Tette (2015), who stated that malnutrition may result in permanent brain function disruption [32] [33]

\section{CONCLUSION}

The provision of tilapia fish flour and sardine fish flour based biscuits for 60 days can improve nutritional status of malnourished children, i.e. the weight/age indicator. The daily consumption of functional biscuits still needs to be improved by adding flavor, color, and shape improvement of the biscuits to increase the amount of biscuit consumption, thereby maximizing the health benefits. Functional nutritious biscuits based on tilapia fish flour and sardine fish flour may be proposed to the government or policymaker to be enforced as a Supplemental Food Recovery Program (PMT-P) in addressing malnourished children or being served as fast food in emergency situations such as natural disasters and hunger

\section{ACKNOWLEDGMENTS}

We would like to thank the Ministry of Research, Technology, and Higher Education that have provided funding through the doctorate scheme program for 2017-2018 on behalf of Dr. Slamet Widodo, S.Pd., M.Kes 


\section{REFERENCES}

[1] R. Litbangkes, Riset Kesehatan Dasar. Jakarta: Balibangkes RI, 2013.

[2] S. Widodo and S. Sirajuddin, "Biscuit Formulation with Addition of Mozambique Tilapia Fish , Round Sardinella Fish and Brown Rice,” Int. J. Sci. Res., vol. 6, no. 8, pp. 1699-1704, 2017.

[3] S. Widodo, H. Riyadi, I. Tanziha, and M. Astawan, "Improving nutritional status of children under five year by the intervention of blondo, snakehead fish [Channa striata], and brown rice [Oryza nivara] based biscuit," $J$. Gizi Pangan, vol. 10, no. 2, pp. 85-92, 2015.

[4] Y. Dong et al., "Prevalence of excess body weight and underweight among 26 Chinese ethnic minority children and adolescents in 2014 : a cross-sectional observational study," BMC Public Health, vol. 18, no. 562, pp. 1-9, 2018.

[5] S. R. Seshadri and J. Ramakrishna, Nutritional Adequacy, Diversity and Choice Among Primary School Children. Singapore: Springer Nature, 2017.

[6] M. F. Sharaf, E. I. Mansour, and A. S. Rashad, "Child nutritional status in Egypt: A Comprehensive analysis of Socioeconomic determinants using A quantile regression approach,” J. Biosoc. Sci., 2018.

[7] M. Zenebe, S. Gebremedhin, C. J. Henry, and N. Regassa, "School feeding program has resulted in improved dietary diversity, nutritional status and class attendance of school children," Ital. J. Pediatr., vol. 44, no. 16, pp. $1-7,2018$.

[8] V. Ch and A. P. Smith, "Current top ics in nutra snacking habit, mental health , and cognitive performance," journals Psychol. public Heal., vol. 9, no. 1/2, pp. 47-52, 2011.

[9] J. Zhang and R. Lynch, "The relationship between primary 5 and 6 students 'perceptions of parental encouragement and their academic achievement in mandarin learning at an international school , BANGKOK," J. Hum. Sci., vol. 9, no. 2, pp. 243-250, 2017.

[10] S. Widodo and S. Siradjudin, "Improving Macro Nutrition Content on Nutritional Biscuits with Substitution of Tilapia Fish Flour, Sardine Fish Flour, and Red Rice Flour,” Asian J. Appl. Sci., vol. 5, no. 5, pp. 1073-1082, 2017.

[11] Sugiyono, Statistika Untuk Penelitian. Bandung: Alfabet, 2010.

[12] Sastroasmoro and Ismail, Dasar-Dasar Metodelogi Penelitian Klinis Edisi 2. Jakarta: CV. Sagung Seto, 2010.

[13] X. Zhang, K. Chen, P. Qu, Y. Liu, and T. Li, "Effect of biscuits fortified with different doses of vitamin A on indices of vitamin A status , haemoglobin and physical growth levels of pre-school children in Chongqing," Public Health Nutr., vol. 13, no. 9, pp. 1462-1471, 2010.

[14] N. Muslihah, A. Khomsan, D. Briawan, and H. Riyadi, "Compliance to small-quantity lipid-based nutrient supplements among rural infants, Bangkalan District," J. Gizi Pangan, vol. 11, no. 2, pp. 115-124, 2016.

[15] S. Widodo, H. Riyadi, I. Tanziha, and M. Astawan, "Improving nutritional status of children under five year by the intervention of blondo, snakehead fish [Channa striata , and brown rice Oryza nivara based biscuit," J. Gizi Pangan, vol. 10, no. 2, pp. 85-92, 2015.

[16] D. Kartika, S. A. Marliyati, L. Kustiyah, and A. Khomsan, "Role of Biscuits Enriched with Albumin Protein from Snakehead Fish, Zinc and Iron on Immune Response of under Five Children," Pakistan J. Nutr., vol. 13, no. 1, pp. 28-32, 2014.

[17] A. P. Den Hartog, W. A. Van Staveren, and I. D. Brouwer, Food habits and consumption in developing countries. Wageningen Netherlands: Wgeningen Academic, 2006.

[18] B. Chew et al., "Chronic consumption of a low calorie, high polyphenol cranberry beverage attenuates inflammation and improves glucoregulation and HDL cholesterol in healthy overweight humans : a randomized controlled trial," Eur. J. Nutr., vol. 0, no. 0, p. 0, 2018.

[19] F. Galvão et al., "Consumption of extra virgin olive oil improves body composition and blood pressure in women with excess body fat : a randomized , double - blinded , placebo - controlled clinical trial,” Eur. J. Nutr., no. 123456789, 2017.

[20] K. Heights, N. Lane, and M. West, "Factors affecting compliance to antihypertensive treatment among adult ... Factors affecting compliance to antihypertensive treatment among adult ...," India J. Community Med., pp. 1417, 2018.

[21] C. A. Mthalib, S. As'ad, and Citrakesumasari, “The Effect of Giving Barusa Kacang Gude on the Body Weight , the Upper Arm Circumference, and the Total Protein Concentration of Elementary School Students With Malnutrition in Bonto Ramba Sub District, Jeneponto Regency," in Proceedings of the International Conference on Healthcare Service Managemen, 2018, pp. 25-28.

[22] A. C. J. Nooyens, B. M. Van Gelder, H. B. Bueno-de-mesquita, M. P. J. Van Boxtel, and W. M. M. Verschuren, "Fish consumption, intake of fats and cognitive decline at middle and older age : the Doetinchem Cohort Study," Eur. J. Nutr., 2017.

[23] A. Utami, D. Pramono, and A. Nugraheni, "Compliance of iron suplementation, prevalence and determinant of anemia in pregnant women," in International Conference on Translational Medicine and Healthh Sciences, 2017, pp. 205-210.

[24] N. R. Galla, P. R. Pamidighantam, B. Karakala, R. Gurusiddaiah, and S. Akula, "Nutritional, Textural and 
Sensory Quality of Biscuits Supplemented with Spinach ( Spinacia Oleracea L.)," Int. J. Gastron. Food Sci., vol. 7, no. June 2016, pp. 20-26, 2017.

[25] A. M. Adams et al., "Impact of fortified biscuits on micronutrient deficiencies among primary school children in Bangladesh," J. plos one, pp. 1-16, 2017.

[26] L. G. Irwin, A. Siddiqi, and C. Hertzman, Early Child Development : A Powerful Equalizer Final Report For The World Health Organizations"s Commision On The Social Determinants Of Health. Vancouver BC: Human Early Learning Partneship Help), 2007.

[27] R. BSN, Standard Biscuit. Jakarta: BSN Indonesia, 2011.

[28] A. Makarimah and L. Muniroh, "Nutritional Status and Body Fat Percentage Correlate with Menarche's Age among Students at Muhammadiyah GKB 1 Elementary School," Media Gizi Indones., vol. 12, no. 2, pp. 191198, 2017.

[29] A. Dwiartama, C. Tresnadi, A. Furqon, and M. F. Pratama, "From Initiative to Movement: The Growth and Evolution of Local Food Networks in Bandung, Indonesia," Asian J. Soc. Sci. Stud., vol. 2, no. 4, pp. 91-98, 2017.

[30] D. Degarege, A. Degarege, and A. Animut, "Undernutrition and associated risk factors among school age children in Addis Ababa, Ethiopia," BMC Public Health, pp. 1-9, 2015.

[31] Y. Dong et al., "Prevalence of excess body weight and underweight among 26 Chinese ethnic minority children and adolescents in 2014 : a cross-sectional observational study," BMC Public Health, vol. 18, no. 562, pp. 1-9, 2018.

[32] I. Picauly and S. M. Toy, "The Determinant Analysis and the Impact of Stunting for School Children School Performance in Kupang and Sumba Timur, NTT," J. Gizi dan Pangan, vol. 8, no. 72, pp. 55-62, 2013.

[33] E. M. A. Tette, E. K. Sifah, and E. T. Nartey, "Factors affecting malnutrition in children and the uptake of interventions to prevent the condition," BMC Pediatr., pp. 1-11, 2015. 